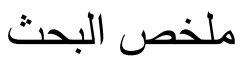

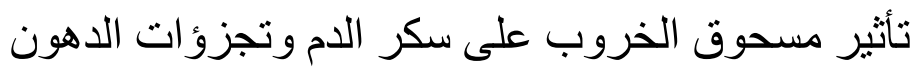

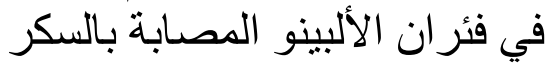

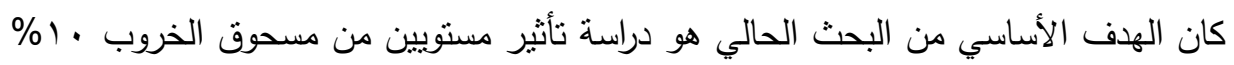
و r\% على سكر الدم وتجزؤات الدهون وقد نم تقسيم ذكور الفئران الأربعون إلى مجموعنين. المجموعة الأولى الضابطة وتتكون من عشرة فئران تم تغذيتها على الوجبة الأساسية والمجموعة الثانية

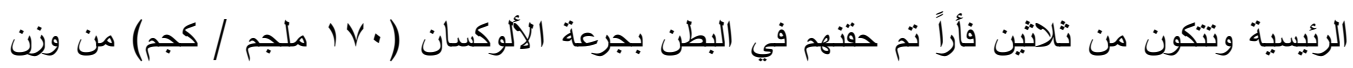

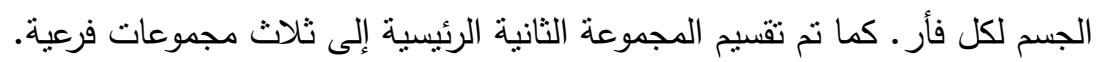

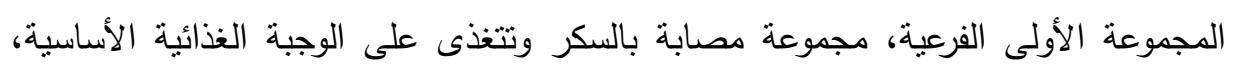

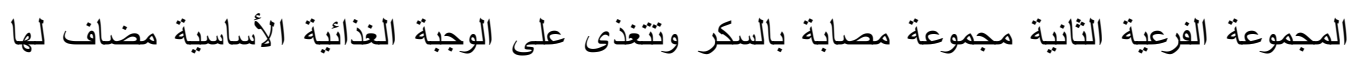

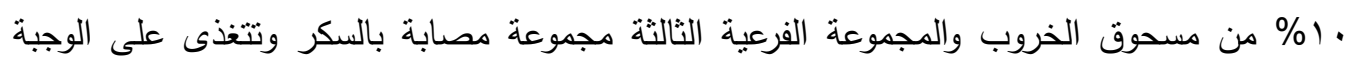
الغذائية الأساسية مضاف إليها • r\% من مسحوق الخروب وذلك لمدة ستة أسابيع. وفي نهاية التجربة تم تجميع عينات الدم وإجراء التحاليل الكيميائية التالية عليها: تقدير سكر الدم والكولستيرول الكلى والجليسريدات الثثلاثية وكوليسترول البروتين مرتفع الكثافة وكوليسترول البروتين منخفض الكثافة وكوليسترول البروتين منخفض الكثافة جداً.

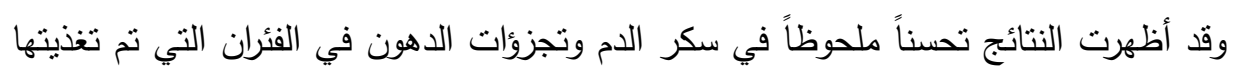

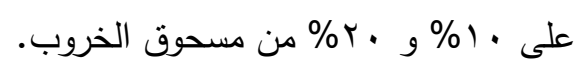
الكلمات المفتاحية: مسحوق الخروب ـ الفئران · سكر الدم ـ تجزؤات الدهون ـ الغذاء المأكول ـ وزن الجسم المكتسب. 


\section{Abstract \\ The Influence of Carob Powder on Serum Glucose and Lipid Profile in Albino Induced Diabetic Rats}

The present study aimed to investigate the effect of two levels of carob powder $(10 \%$ and $20 \%)$ on serum glucose and lipid profile. Forty male Sprague-Dawley rats were divided into two groups. The First group control negative group consisted of (10) rats fed on basal diet. The second main group consisted of (30) rats were injected intraperitoneal with alloxan monohydrate in single dose $(170 \mathrm{mg} / \mathrm{Kg})$ body weight. The second main group was divided into three subgroups (10 rats each). Subgroup (1); diabetic group was fed on basal diet only control positive group, Subgroup (2); diabetic group was fed on basal diet plus $10 \%$ carob powder and subgroup (3); diabetic group was fed on basal diet plus $20 \%$ carob powder for six weeks. At the end of the experimental period, serum samples was collected to measure serum glucose (SG), total cholesterol (TC), triglyceride (TG), high-density lipoproteins (HDL), lowdensity lipoproteins (LDL) and very-low-density lipoproteins (VLDL). The obtained results revealed that feeding rat's $10 \%$ and $20 \%$ carob powder improved serum glucose and lipid profile parameters in the experimental rats.

\section{Key words:}

carob powder, rats, serum glucose, lipid profile, feed intake, body weight gain. 
Pang, S.F., Tang, F. and Tang, P.L. (1985): Alloxan-induced diabetes and the pineal gland. Differential effects on the level of pineal N-acetyl serotonin, pineal melatonin and serum melatonin. J. Pineal. Res., 2 (1): 79 - 85.

Russell, D. F. (1983): MSTAT Director crop and Soil sciences department, Michigan State University, version 2.10.

Shapiro, K. and Gong ,WC. (2002): Natural products used for diabetes. J Am Pharm Assoc 42(2): 217- 226.

Sharma AK. (1993): Diabetes Mellitus and Its Complications: An Update. New Delhi: Mac. Millan. p. 18-159.

Suji, G. and Sivakami, S. (2003): Approaches to the treatment of diabetes mellitus; an overview. Cell Mol Biol; 49: 635 - 639.

Tabatabai, A., and Li, S. (2000): Dietary fiber and type 2 diabetes. Clin Excell Nurse Pract; 4(5): 272-6.

Tietz, N.W. (1995): Clinical Guide to Laboratory tests. 3rd ed. Philadelphia. WB. Saunders, 268-273.

Warnick, G.R.; Benderson, V. and Albers, N. (1983): Selected Methods Clin. Chem. (10): 91-99.

Wild, S.; Roglic, G.; Green, A.; Sicree, R. and King, H. (2004): Global prevalence of diabetes estimates for the year 2000 and projections for 2030. Diabetes care 27: $1047-1053$.

Williams, DR.; James, WP. and Evans, IE. (1980): Dietary fibre supplementation of a 'normal' breakfast administered to diabetics. Diabetologia. May; 18(5): 379-83.

Wolever, TM. (2003): Carbohydrate and the regulation of blood glucose and metabolism. Nutr Rev.; (61) (5 Pt 2): S40-8.

Yukiko,Y.; Ikuyo, S.; Akiko, N.; Shigeru, S.; Naoki, I. and Shiho, I. (2000): Improved Hypolipidemic Effects of Xanthan Gum-Galactomannan Mixtures in Rats. Biosci. Biotechnol. Biochem. 64(10): 2165-2171.

Zunft, H. J. F.; Luder, W.; Harde, A.; Haber, B.; Graubaum, H. J. and Gruenwald, J. (2003): Carob pulp preparation rich in insoluble fiber lowers total and LDL cholesterol in hypercholesterolemic patients. European Journal of Nutrition; 42 (5): 235 - 24. 
Jim, D. (2005): Phytochemical and Ethnochemical datbases, Beltsvilla Argriculture Research Cennter.Green Farmacy Garden, 1-200.

Kamal, M. E. Y.; El-Manfaloty, M. M. and Ali, H. M. (2013): Assessment of Proximate Chemical Composition, Nutritional Status, Fatty Acid Composition and Phenolic Compounds of Carob (Cerationia Siliqua L.), J. Food and Public Health, 3(6): 304-308.

Klaus, S.; Pultz, S.; Thone-Reineke, C. and Wolfram, S. (2005): Epigallocatechin gallate attenuates diet-induced obesity in mice by decreasing energy absorption and increasing fat oxidation.Int. J. Obes (Lond); 29:615-623.

Kritchevsky, D .(1982): dietary fiber and disease. Bull. N. y. Acad.Med: 58(3):230-241.

Kumazawa, S.; Taniguchi, M.; Suzuki, Y.; Shimura, M.; Kwon, M.S. and Nakayama, T. (2002) :Antioxidant activity of polyphenols in carob pods. J. Agric. Food Chem. Jan. 16; 50 (2) 373-7..

Makris, D. P.; Kefalos, P. (2004): Carob pods (Ceratonia silique L.) as a source of polyphenolic antioxidants. Food Technol. Biotechnol.m 42,105-108.

Manisha, C.; Abhimanyu, G.; Dieter, L; Klaus, V. B.; Scott, M. G. and Linda, J. (2000): Beneficial Effect of High Dietary Fiber Intake in Patients with Type 2 Diabetes Mellitus. N Engl, J. Med.; 342: 1392-1398.

Manning, P.J.;.Sutherland, W. H. F.; Wa;ker, R.J.; Williams, S. M. D.; Jong S.A. and Ryalls, A.R. (2004): Effect of highdose vitamin E on insulin resistance and associated parameters in overweight subjects. Diabetes Care; (27): 2166-2171.

Mirhaydar, H. (1994): Plant information: Plant Usage in Disease Treatment. Farhang Islami Press, Iran, pp: 115.

Mokhtari, M. ; Sharifi, S. and Shahamir, T. M. (2011): The Effect of Hydro Alcoholic Seeds Extract of Ceratonia siliqua on the Blood Glucose and Lipids Concentration in Diabetic Male Rats. International Conference on Life Science and Technology IPCBEE vol. (3).

Mozaffarian, V. A. (1996): Dictionary of Iranian Plant Names. Farhang Moaser Publication. Tehran. pp : 102-103.

O'Connel, B. (2001): Select vitamins and minerals in the management of diabetes. Diabetes Spectrum, (14): 133 - 148.

Oven, R. W.; Haubner, R.; Hull, W. E.; Erben, G; Spiegelhalder, B.; Bartsh, H. and Haber, B. (2003): Isolation and structure elucidation of the major individual polyphenols in carob fiber. Food and Chemical Toxicology Volum 41(12) p.1727-1738.

Packer, L. (1991) :Protective Role of vitamin E in biological system,Am J Clin Wutr.; (53):1050-1055. 


\section{References:}

Alan, C. T. and Becky, P. (1981): Effects of locust bean gum on glucose tolerance, sugar digestion, and gastric motility in rats. J. Nutr.; 11: 21522156.

Allian, C.C.; Poon, L.S.; Chan, C.S.G. and Richmond, W. (1974): Enzymatic colourimetric method of the determination of plasma total cholesterol, Clin. Chem. (20): 470.

Anon. (1977): First Report of The American Institute of Nutrition J. Nutrition 107: No. (7), 1340-1348.

Anon. (1980): Second Report of The American Institute of Nutrition J. Nutrition. No. (8), 110: 1726.

Ble, C. JL.; Carmona, D. ED.; Mendes ,J.; laries,M. FJ..; Medina, S. R. and Cleva, VG. (2005): Effect of a-tocopherol on the metabolic control and oxidative stress in female type 2 diabetics. Biomed Pharmacother; (59): 290-295.

Burget, L.; Caton, S.; Bai, Y.; Spangler, L.; Gruendel, S.; Koebnick, C.; Bidlingmaier, M. (2007): Longterm effects of carob pulp preparations in insoluble fiber on metabolism, body weight and leptin levels in rats, Exp Clin Endocrinol Diabetes ,115 - P01_124.

Bursell, S-E.; Clermont, AC. ;Aiello, LP. ;Aiello, LM.; Schlossman, DK. and Feener, EP. (1999): High-dose vitamin E supplementation normalizes retinal blood flow and creatinine clearance in patients with type 1 diabetes. Diabetes Care; (22): 1245-1251.

David, M. (1993): Nathanlong-Term Complications of Diabetes Mellitus.N Engl Med. 328: 1676-1685. diabetes. Diabetes Spectrum; 14: 133-148.

Dulloo, A. G.; Duret, C.; Rohrer, D., Girardier, L.; Mensi ,N.; Fathi ,M.; Chantre, P. and Vandermander, J. (1999): Efficacy of a green tea extract rich in catechin polyphenols and caffeine in increasing 24-h energy expenditure and fat oxidation in humans. Am J Clin Nutr;70:1040-5.

Fossati, S. F. and Prancipel, R. (1982): Triglycerides determination after enzymatic hydrolysis. Clin. Chem., 28: 2077.

Friedewald, W.T.; Levy, R. I. and Fredrickson, D.S. (1972): Determination of high density lipoprotein cholesterol by selective precipitation. Clin. Chem. (18): 499 - 502.

Hayashi, T.; Nozawa, M.; Sohmiya, K.; Toko, H.; Nakao, M. and Okabe, M. (1998): Efficacy of pancreatic transplantation on cardiovascular alterations in diabetic rats: an ultrastructural and immunohistochemical study. Transplant Proc; (30): 335-8.

Ilwy, Y.M.E. (2003): The effect of some kinds of sea food (fish) on blood lipid profile in rats. Ph. D. Thesis, Faculty of Specific Education, Ain Shams University, Egypt. 
Table (4) revealed that the HDL in subgroups (2) and (3) was increased when compared with subgroup (1) control positive group while, the serum LDL and VLDL were decreased in subgroups (2) and (3) when compared with subgroup (1) especially at the end of the experiment. This results agree with Oven et al,.(2003). This might be due to fat soluble tocopherol is among antioxidants found in (ceratonia siliqua L.) Williams, et al., (1980). This compound prevents oxidation of unsaturated fatty acids; thereby changes cholesterol LDLC,HDL-C and triglyceride plasma levels Packer, (1991). Alpha-tocopherol can reduce HDL $-\mathrm{C}$ and LDL- $\mathrm{C}$ concentrations in diabetic rats Mokhtari et al,.(2011).

\section{In conclusion}

The results showed that the $20 \%$ was better than $10 \%$ carob powder and decreased the serum glucose and the lipid profile so we recommend utilizing it in the hyperglycemic and hypercholesterolemic patient's diets. 
Table (3) revealed that the total cholesterol and triglycerides in subgroups (2) and (3) was decreased when compared with control positive group in both. This results agree with Burget et al., (2007) who found that carob fibers and polyphones have been shown to exert beneficial effects on metabolic parameters (cholesterol, triglycerides), this maight be carob fiber contains water soluble and water insoluble polyphenols which exhibit considerable natural antioxdative activity and can contribute to a amoe favorable balance between free radicals (oxidants|) and antioxidants Oven et al.,(2003).

Manisha et al., (2000) ; Tabatabai and $\mathrm{Li}(\mathbf{2 0 0 0 )}$ ) concluded that usage of fiber decreases total cholesterol, LDL-C and triglyceride levels, while HDL$\mathrm{C}$ level showed no significant difference. They declared that the reason for this decline is an increase in bile acid due to fiber intake, which reduces cholesterol uptake.

Zunft et al., (2003) demonstrated that daily consumption of food products enriched with carob fiber shows beneficial effects on human blood lipid profile and may be effective in prevention and treatment of hypercholesterolemia.

\subsection{The effect of carob powder on HDL, LDL and VLDL}

Table (4) revealed that the LDL- cholesterol and VLDL-cholesterol in (control positive) Subgroup (1) were significantly increased $(p<0.01)$. While, the mean value of HDL-cholesterol was significantly decreased $(p<0.01)$ when compared with control negative group. The present data agree with Mokhtari et al., (2011).

Table (4 ) Lipid profile in all studied groups

\begin{tabular}{|c|c|c|c|c|c|c|}
\hline \multirow{2}{*}{$\begin{array}{c}\text { Parameter } \\
\text { groups }\end{array}$} & \multicolumn{2}{|c|}{$\begin{array}{l}\text { HDL-cholesterol } \\
\text { (mg/dl) }\end{array}$} & \multicolumn{2}{|c|}{$\begin{array}{l}\text { LDL-cholesterol } \\
\text { (mg/dl) }\end{array}$} & \multicolumn{2}{|c|}{$\begin{array}{l}\text { VLDL-cholesterol } \\
\text { (mg/dl) }\end{array}$} \\
\hline & $\begin{array}{l}\text { End of the } \\
3^{\text {rd }} \text { week }\end{array}$ & $\begin{array}{c}\text { End of the } \\
6^{\text {th }} \text { week }\end{array}$ & $\begin{array}{l}\text { End of the } \\
3^{\text {rd }} \text { week }\end{array}$ & $\begin{array}{l}\text { End of the } \\
6^{\text {th }} \text { week }\end{array}$ & $\begin{array}{c}\text { End of the } \\
3^{\text {rd }} \text { week }\end{array}$ & $\begin{array}{c}\text { End of the } \\
6^{\text {th }} \text { week }\end{array}$ \\
\hline $\begin{array}{l}\text { Control negative } \\
\text { group }\end{array}$ & $47.03^{\mathrm{ab}} \pm 1.49$ & $48.12^{\mathrm{a}} \pm 1.55$ & $47.69^{\circ} \pm 1.74$ & $49.44^{\mathrm{e}} \pm 1.32$ & $10.62^{\mathrm{ef}} \pm 0.26$ & $10.18^{\mathrm{f}} \pm 0.36$ \\
\hline $\begin{array}{l}\text { Control positive } \\
\text { Subgroup (1) }\end{array}$ & $37.72^{\mathrm{f}} \pm 1.12$ & $40.77^{ \pm} \pm 0.87$ & $86.28^{\mathrm{a}} \pm 1.44$ & $84.77^{\mathrm{a}} \pm 3.45$ & $13.61^{b} \pm 0.43$ & $14.21^{\mathrm{a}} \pm 0.44$ \\
\hline $\begin{array}{l}10 \% \text { carob powder } \\
\text { Subgroup (2) }\end{array}$ & $42.25^{\mathrm{d}} \pm 1.14$ & $44.03^{\mathrm{c}} \pm 0.84$ & $71.39^{b} \pm 1.55$ & $60.47^{\circ} \pm 3.58$ & $12.06^{\mathrm{d}} \pm 0.51$ & $13.06^{\mathrm{c}} \pm 0.51$ \\
\hline $\begin{array}{l}20 \% \text { carob powder } \\
\text { Subgroup (3) }\end{array}$ & $44.39^{\mathrm{c}} \pm 1.86$ & $46.29^{b} \pm 1.85$ & $68.33^{b} \pm 1.48$ & $55.27^{\mathrm{d}} \pm 1.65$ & $11.04^{\circ} \pm 0.49$ & $12.04^{\mathrm{d}} \pm 0.24$ \\
\hline
\end{tabular}

Mean \pm SE, $\mathrm{SE}=$ Standard Error, Values followed by the same letter within the same column were not significantly different $(\mathrm{P}<0.01)$. 
The consumption of high fiber foods can decrease plasma glucose concentration. Fibers are meanly carbohydrates produced by plants. However, human lack necessary enzyme to digest them. Chemical structure of polysaccharides fibers changes some features of digestive tract such as $\mathrm{PH}$, folding and ionic charge. Adhesive composition of polysaccharides increases food particles adhesion which then, delays stomach offloading on one hand, and prevents sugar uptake by small intestine on the other Yukiko (2000). Lowering of serum glucose concentration can decrease insulin level.

Carbohydrates could modify blood glucose concentration through effecting the uptake of materials and influencing fermentation in large intestine Wolever (2003). Similarly, food fibers can decrease blood glucose level by releasing insulin from liver and by elevating receptors sensitivity to insulin Tabatabai and Li (2000). In addition, it has been suggested that dietary carbohydrates play an important role in glucose homeostasis; there fore, they can control diabetes symptoms Alan and Becky (1981).

Tocopherol has positive effects on controlling metabolic processes in diabetic patients; this effect is due to its antioxidant effect on protein glycosylation and insulin sensitivity O'Connel (2001). Furthermore, long term usage of tocopherol decreases blood sugar in diabetic and healthy people Ble et al.,(2005). There are some information about lowering plasma ALT by tocopherol and it is possible that simultaneous decline of glucose and insulin levels are the results of improvement in liver cells functions as well as decreasing liver resistance to insulin and glucose production Manning et al,. (2004). Tocopherol also in improves insulin function through its effects on plasma membrane Bursell (1999).

\subsection{The effect of carob powder on serum cholesterol and triglycerides}

Table (3) revealed that the total cholesterol and triglycerides in control positive subgroup (1) were increased significantly $(p<0.01)$ when compared with control negative group. The present data agree with Mokhtari et al., (2011).

Table (3) Serum cholesterol and triglycerides in all studied groups

\begin{tabular}{|c|c|c|c|c|}
\hline \multirow[t]{2}{*}{ Parameter groups } & \multicolumn{2}{|c|}{$\begin{array}{c}\text { Cholesterol } \\
\text { (mg/dl) }\end{array}$} & \multicolumn{2}{|c|}{\begin{tabular}{|c|}
$\begin{array}{c}\text { Triglycerides } \\
(\mathrm{mg} / \mathrm{dl})\end{array}$ \\
\end{tabular}} \\
\hline & End of the $3^{\text {rd }}$ week & End of the $6^{\text {rth }}$ week & End of the $3^{\text {rd }}$ week & End of the $6^{\text {rth }}$ week \\
\hline Control negative group & $105.3^{\mathrm{e}} \pm 0.71$ & $107.8^{\mathrm{e}} \pm 1.70$ & $53.08^{\mathrm{f}} \pm 1.02$ & $50.92^{\mathrm{g}} \pm 1.92$ \\
\hline $\begin{array}{l}\text { Control positive } \\
\text { Subgroup (1) }\end{array}$ & $137.6^{\mathrm{a}} \pm 0.74$ & $139.7^{\mathrm{a}} \pm 2.11$ & $68.05^{b} \pm 0.96$ & $71.05^{\mathrm{a}} \pm 2.20$ \\
\hline $\begin{array}{l}10 \% \text { carob powder } \\
\text { Subgroup (2) }\end{array}$ & $125.7^{\mathrm{b}} \pm 0.53$ & $117.6^{\mathrm{c}} \pm 3.03$ & $60.70^{\mathrm{d}} \pm 2.60$ & $65.27^{\mathrm{c}} \pm 2.56$ \\
\hline $\begin{array}{l}20 \% \text { carob powder } \\
\text { Subgroup (3) }\end{array}$ & $123.8^{\mathrm{b}} \pm 0.54$ & $113.6^{\mathrm{d}} \pm 2.47$ & $55.21^{\mathrm{e}} \pm 0.72$ & $60.22^{\mathrm{d}} \pm 1.18$ \\
\hline
\end{tabular}

Mean $\pm \mathrm{SE}, \mathrm{SE}=$ Standard Error,Values followed by the same letter within the same column were not significantly different $(\mathrm{P}<0.01)$. 
The result given in Table (1) revealed that body weight gain showed significant differences among all studied groups at $(\mathrm{p}<0.01)$ in third and sixth weeks in experimental period. By the end of third and sixth weeks the data recording (35.24 \pm 0.11$)$ and $(59.92 \pm 0.32)$ for control negative group of experimental rats, meanwhile, the body weight gain in subgroups $(1,2,3)$ decreased significantly at $(\mathrm{p}<0.01)$. the third weeks recording $(11.99 \pm 0.21$, $14.73 \pm 0.23$ and $17.40 \pm 1.87$ ) while the body weight gain in sixth weeks recording $(29.76 \pm 1.56,31.15 \pm 0.34$ and $33.01 \pm 0.21)$; respectively.

\subsection{The effect of carob powder on serum glucose in all studied groups.}

Diabetes is considered one of the most prevalent diseases of endocrine system. As a result of this disease, the normal body metabolic functions become disordered. In spit of induced hyperglycemia, many body cells are not able to uptake glucose for nourishment Hayashi (1998).

The data in the Table (2) was decreased significantly $(\mathrm{p}<0.01)$ at serum glucose in all studied groups when compared with control positive group, especially subgroup (3) which fed on basil diet plus $20 \%$ carob powder.

\section{Table (2) Serum glucose in all studied groups}

\begin{tabular}{|l|c|c|}
\hline \multirow{2}{*}{ Parameter groups } & \multicolumn{2}{|c|}{ Serum glucose } \\
\cline { 2 - 3 } & End of the $3^{\text {rd }}$ week & End of the $6^{\text {th }}$ week \\
\hline Control negative group & $107.7^{\mathrm{d}} \pm 1.44$ & $109.2^{\mathrm{d}} \pm 0.52$ \\
\hline $\begin{array}{l}\text { Control positive } \\
\text { Subgroup (1) }\end{array}$ & $281.1^{\mathrm{ab}} \pm 2.68$ & $294.8^{\mathrm{a}} \pm 2.92$ \\
\hline $\begin{array}{l}10 \% \text { carob powder } \\
\text { Subgroup (2) }\end{array}$ & $278.2^{\mathrm{bc}} \pm 3.90$ & $270.48^{\mathrm{bc}} \pm 2.43$ \\
\hline $\begin{array}{l}20 \% \text { carob powder } \\
\text { Subgroup (3) }\end{array}$ & $273.5^{\mathrm{bc}} \pm 1.12$ & $260.9^{\mathrm{c}} \pm 3.75$ \\
\hline
\end{tabular}

Mean $\pm \mathrm{SE}, \mathrm{SE}=$ Standard Error,Values followed by the same letter within the same column were not significantly different $(\mathrm{P}<0.01)$.

The results given in Table (2) revealed that the serum glucose showed significant differences among all the studied groups and there combination with different levels $(10 \%$ and $20 \%)$ carob powder groups were $(p<0.01)$ in experimental period.

The serum glucose decreased significantly at $(\mathrm{p}<0.01)$ for subgroups (2) and (3) were recording $(278.2 \pm 3.90 \mathrm{mg} / \mathrm{dl}$ and $273.5 \pm 1.12 \mathrm{mg} / \mathrm{dl})$ for experimental rats (treated group fed on basal diet plus (10\% and 20\%) carob powder.

This might be due to that carob powder reduced glucose percent in blood due to its content of high percent fiber, carbohydrates and tocopherol Kamal et al., (2013). 
density lipoprotein cholesterol (VLDL) were calculated according to the equation of Friedewald, et al., (1972).

\subsubsection{Statistical Analysis}

Data were analyzed applying T-test using SPSS program version 16 and the data was analyzed with analysis of variance (ANOVA) procedures by using the MSTAT-C Statistical software package Russell (1983). Where the F-test showed significant differences among means Duncan multiple range test performed at the 0.05 level of probability to separate means.

\section{Results and Discussion:}

\subsection{The effect of carob powder on Feed intake (g) and body weight gain (\%)}

The results given in Table (1) revealed that feed intake showed significant differences among all studied groups at $(\mathrm{p}<0.01)$ in third and sixth weeks in experimental period. By the end of third and sixth weeks, the data showed no significant differences between control negative group and control positive subgroup (1). However, in the third weeks the data showed significant differences between control negative group recording $(17.89 \pm 0.53 \mathrm{~g} / \mathrm{rat})$ and subgroup (2) and (3) including feed intake $(10 \%$ and $20 \%)$ carob powder; respectively. Which increased significantly at $(\mathrm{p}<0.01)$ recording $(19.42 \pm 0.69$ $\mathrm{g} / \mathrm{rat})$ and $(19.86 \pm 0.59 \mathrm{~g} / \mathrm{rat})$; respectively. On the other hand, the data of feed intake showed significant differences between control positive subgroup (1) and subgroups (2 and 3). However, in the sixth weeks the data showed significant differences between control negative group recording $(18.91 \pm 0.44 \mathrm{~g} / \mathrm{rat})$ and subgroup (2) and (3); respectively. Which increased significantly at $(\mathrm{p}<0.01)$ recording $(20.32 \pm 0.54 \mathrm{~g} / \mathrm{rat})$ and $(20.92 \pm 0.44 \mathrm{~g} / \mathrm{rat})$; respectively. Likewise, there were significant differences in feed intake between subgroup (1) and subgroups (2) and (3).

There were significant differences in feed intake between subgroup (2) and (3). However, subgroup (3) increased significantly at ( $\mathrm{p}<0.01)$.

Table (1) Feed intake (g) and body weight gain (\%) in all studied groups.

\begin{tabular}{|l|c|c|c|c|}
\hline \multirow{2}{*}{ Parameter groups } & \multicolumn{2}{|c|}{ Feed intake } & \multicolumn{2}{c|}{ Body weight gain } \\
\cline { 2 - 5 } & $\begin{array}{c}\text { End of the } 3^{\text {rd }} \\
\text { week }\end{array}$ & $\begin{array}{c}\text { End of the 6 } \\
\text { week }\end{array}$ & $\begin{array}{c}\text { End of the 3 } \\
\text { wdeek }\end{array}$ & $\begin{array}{c}\text { End of the 6 } \\
\text { week }\end{array}$ \\
\hline Control negative group & $17.89^{\mathrm{e}} \pm 0.53$ & $18.91^{\mathrm{d}} \pm 0.44$ & $35.24^{\mathrm{b}} \pm 0.11$ & $59.92^{\mathrm{a}} \pm .0 .32$ \\
\hline $\begin{array}{l}\text { Control positive } \\
\text { Subgroup (1) }\end{array}$ & $18.09^{\mathrm{e}} \pm 0.38$ & $19.06^{\mathrm{d}} \pm 0.23$ & $11.99^{\mathrm{h}} \pm 0.21$ & $29.76^{\mathrm{e}} \pm 1.56$ \\
\hline $\begin{array}{l}10 \% \text { carob powder } \\
\text { Subgroup (2) }\end{array}$ & $19.42^{\mathrm{cd}^{\mathrm{d}}} \pm 0.69$ & $20.32^{\mathrm{b}} \pm 0.54$ & $14.73^{\mathrm{g}} \pm 0.23$ & $31.15^{\mathrm{d}} \pm 0.34$ \\
\hline $\begin{array}{l}20 \% \text { carob powder } \\
\text { Subgroup (3) }\end{array}$ & $19.86^{\mathrm{bc}^{\mathrm{c}}} \pm 0.59$ & $20.92^{\mathrm{a}} \pm 0.44$ & $17.40^{\mathrm{f}} \pm 1.87$ & $33.01^{\mathrm{c}} \pm 0.21$ \\
\hline
\end{tabular}

Mean \pm SE, SE $=$ Standard Error, Values followed by the same letter within the same column were not significantly different $(\mathrm{P}<0.01)$. 
Dulloo et al., (1999) and in mice Klaus et al., (2005). Therefore, carob fiber may exert beneficial effects on postprandial lipid metabolism and substrate utilization potentially related to the secretion of gut hormones.

The aim of this study was to investigate the influence of carob powder on serum glucose and lipid profile in Albino rats suffering from diabetes.

\section{Materials and Methods:}

\subsection{Materials:}

Five Kg. of carob powder (Ceratonia Siliqua) were obtained from Aswan Governorate where carob is cultivated. Samples were stored at $18^{\circ} \mathrm{C}$ and analyzed within 2 months.

\section{Methods:}

\subsection{Biological Experiment}

\subsubsection{Experimental Animals}

Forty adult male white albino rats (Sprague dawley strain) weighing between 100 and 120 grams were obtained from the animal house of the Faculty of Medicine, Assiut University. The animals were housed as groups in wire cages under the normal laboratory conditions and were fed on basal diets for a week as adaptation period.

\subsubsection{Preparation of the Basil Diet}

The basal diet was prepared according to Ilwy (2003). The salt mixture used according to Anon (1977). The vitamin mixture used according to Anon (1980).

\subsubsection{Experimental Design:}

The rats were randomly divided into two groups. The First group control negative group consisted of (10) rats and was fed on basal diet. The second main group consisted of (30) rats and were injected intraperitoneal with alloxan monohydrate. $\left(\mathrm{C}_{4} \mathrm{H}_{2} \mathrm{~N}_{2} \mathrm{O}_{4} \cdot \mathrm{H}_{2} \mathrm{O}\right)$ in single dose of $(170 \mathrm{mg} / \mathrm{Kg})$ body weight according to Pang et al., (1985). The second main group was divided into three subgroups (10 rats each) Subgroup (1); diabetic group was fed on basal diet only (control positive group), Subgroup (2); diabetic group was fed on basal diet plus $10 \%$ carob powder and subgroup (3); diabetic group was fed on diet plus $20 \%$ carob powder for six weeks.

\subsubsection{Blood Sampling:}

At the end of the experiment, rats were fasted overnight and anesthetized. Blood samples were collected from all animals from the retroorbital plexus. Serum samples were used for determination of serum glucose Tietzy (1995) total cholesterol (TC) Allian et al., (1974), triglycerides (TG) Fossati and Prancipel (1982), high density lipoprotein cholesterol (HDL) Warnick et al., (1983), low density lipoprotein cholesterol (LDL) and very low 


\title{
The Influence of Carob Powder on Serum Glucose and Lipid Profile in Albino Induced Diabetic Rats
}

\author{
Moshera M. El-Manfaloty* $\quad$ Hend M. Ali*
}

\section{Introduction:}

Diabetes Mellitus is an endocrine disease that causes disorders in carbohydrate, lipid and protein metabolism. This disease is defined by hyperglycemia which is brought about by a deficiency in insulin production and or by resistance to it David (1993). Hyperglycemia can give rise to other disorders in eyes, kidney, vessels and nervous system Sharma (1993).

At present, over 150 million persons suffer from hyperglycemia throughout the world; its predicted that this number will be about 366 millions in 2030 Wild et al., (2004). The most important and indeed the main method for treating diabetes is the used of insulin and hypoglycemic drugs however, these substances have various unfavourite side effect Suji and Sivakami (2003). Medicinal herbs can have applications in treatment of many diseases such as diabetes but their effectiveness has not been investigated properly and needs to be validated Shapiro and Gong (2002). One of these midicial plants is carob tree (Ceratonia Siliqua) from fabaceae family whice has a height of 7$12 \mathrm{~m}$. this evergreen tree is often monoecious and has pinnate leaves and raceme flowers Mozaffarian (1996). (Ceratonia Siliqua) is native to Mediterancan area. In some area, carob seeds is used like tea and coffee Mirhaydar (1994). In fact, it is a suitable replacement for cocoa because it lacks caffine and theobromine .

Williams et al.,(1980) and Jim (2005) reported that (Ceratonia Siliqua) is useful to treat and improve diabetes symptoms because it has compounds such as fibers, phytosterols and tocopherol. Kritchevsky (1982) reported that fibers are able to bind to cholesterol and phospholipids thereby interferes in their uptake.

In humans, consumption of carob fiber was shown to have a high antoxidant capacity Kumazawa et al., (2002) lower serum cholesterol and serum triglycerids Zunft et al., (2003). Furthermore, other studies showed that polyphenols may increase fat oxidation and energy expenditure in humans

\footnotetext{
* Home Economic Department, Nutrition and Food Science, Faculty of Specific Education, Assiut University, Assiut, A. R. Egypt.

** Corresponding Author: Hendma20@yahoo.com (Hend M. Ali)

Home Economic Department, Nutrition and Food Science, Faculty of Specific Education, Assiut University, Assiut, A. R. Egypt.
} 